\title{
COOPERATIVE SOCIETY AS AN ENTREPRENEURSHIP VEHICLE FOR ACTUALISING SUSTAINABLE DEVELOPMENT GOALS: A CASE STUDY OF OSUN STATE
}

\author{
T. F. Jiboye \\ Obafemi Awolowo University, Ile-Ife \\ M. O. Akinyosoye \\ Obafemi Awolowo University, Ile-Ife \\ C. A. Akinbami \\ Obafemi Awolowo University, Ile-Ife \\ Segun Omisore \\ University of East London, United Kingdom
}

\&

A. O. Adegbolagun

University of Ibadan, Ibadan

\begin{abstract}
Studies have affirmed that restructuring for sustainable development is a process involving three essential elements; feasible industrial growth to fulfil basic socio-economic needs; ensuring maximum development of human resources and achieving greater socio justice through a more equitable income distribution. Unfortunately, none of these is satisfactorily manifesting in African nations. In Nigeria, unemployment rate is increasing among the youth and young graduates. Globally, cooperatives societies have become well appreciated as a strong vehicle for promoting economic empowerment particularly among the youth and other vulnerable and marginalised groups. This will be a vehicle to eradicate poverty among the youth thereby fulfilling the first Sustainable Development Goal (SDG). This study examined the contributions of cooperatives societies to poverty eradication among members and national development; investigated how cooperative societies can be better positioned to achieve the Sustainable Development Goals in Nigeria; and determined the factors affecting the performance of cooperatives in Nigeria. Two thousand Nine Hundred and seventy-two respondents from all 1,486 cooperative societies in Osun State were sampled. Result showed that cooperative societies have ability for economic significance, employment creation, income generation, poverty reduction, environmental sustainability and institutional capacity building. The paper concluded that cooperative societies, if well harnessed, could be used to make local entrepreneurs have access to finance and thereby eradicating poverty and so fulfil goal one of the sustainable development goals.
\end{abstract}

Keywords: Sustainable Development Goals, Cooperative Societies, Poverty Eradication and Entrepreneurship.

\section{Introduction}

With an increasingly globalising world economy, it might have been expected that those countries classed as 'developing' would catch up, but the opposite has happened. In some countries such as Brazil, growth has been accompanied by growing inequality, and the benefits 
have not filtered down enough to the poor. In others, such as those in sub-Saharan Africa, growth has slowed down even to the point of going into reverse (Okereke, 2012). Everywhere growing populations swell, the numbers in poverty increases, even when there is economic growth (Johnston Birchall, 2004). Also, we know that growth comes at a cost; the environmental degradation that often accompanies it tips more people into poverty. Nigeria, which is one of Africa's most endowed countries, is no exception to these problems. Despites its vast oil wealth and other natural and human resources, $35 \%$ of the population live in extreme poverty while as much as $54 \%$ are poor in relative terms. Almost $52 \%$ live on less than a dollar a day (World Bank, 2016).

The United Nations Millennium Declaration and its goals set out issues that must be addressed if we are to strengthen the foundations of a more peaceful, prosperous and just world. This Millennium Development Goals (MDG) were the focused agenda for the world's development by multi and bilateral organisations, governments and civil societies seeking to find innovative ways to reach the goals by 2015. Sequel to the evaluation of the achievement of the MDGs, SDGs discussions came on board to include new 17 goals with 169 targets covering a broad range of sustainable development issues. These included ending poverty and hunger, improving health and education, making cities more sustainable, combating climate change, and protecting oceans and forests (UN, Department of Economic and Social Affairs, 2014).

For SDGs to achieve the desired goals, different tools and models need to be implemented at the international, national, and local levels among groups of people with mutual interest. Cooperation among people has existed since history has been recorded. Traditional forms of cooperation involved community members voluntarily pooling financial resources through contributions, which was an association of people having the common objectives of mobilizing resources, especially finance, and distributing it to members on rotational basis (UN, Department of Economic and Social Affairs, 2014) Currently, cooperatives societies are recognised as important instrument for socio economic improvement of a community. Cooperatives societies are essentially self-help groups of people who get together to meet their needs (Virendra Kumar et al, 2015) they come in several forms.

Consumer cooperatives provide their members with food and other products they need, while housing cooperatives provide shelter and worker cooperatives provide decent work. Credit cooperatives provide savings and credit, while Agricultural cooperatives help farmers to organize the inputs, they need to grow crops and keep livestock, and then help them to market and process their products. ICA (1995) also recognised their importance as an autonomous association of persons united voluntarily to meet their common economic, social, and cultural needs and aspirations through a jointly owned and democratically controlled enterprise. Cooperatives are based on the values of self-help, self-responsibility, democracy, equality, equity, and solidarity. In the tradition of their founders, cooperative members believe in the ethical values of honesty, openness, social responsibility, and caring for others. Cooperatives are thriving enterprises which contribute in significant ways to reducing poverty, promoting gender equality, providing health care services, ensuring environmental sustainability, and working through partnerships with a wide range of actors (Virendra Kumar et al, 2015).

However, many are not taking into consideration the unique contribution that cooperatives can make, due to the fact that cooperatives have had a mixed history and the lack of visibility of the cooperative model. The past record of those so-called cooperatives set up and controlled by government, and which miserably failed to lead to any economic and social development, 
are not part of the legacy of cooperatives as these are not true cooperatives. Thus, there exists the ever important need to showcase what real cooperative enterprises have been and are capable of. Given this background this paper seeks to conceptualise the expected and actual functioning of cooperatives societies in Nigeria in line with the SDG. Specifically, the paper will attempt to answer the following questions:

- What are the contributions of cooperatives to alleviate poverty from their members and to national development?

- How can cooperative societies be better positioned to achieve the Sustainable Development Goals in Nigeria?

- What are the factors affecting the performance of cooperatives in Nigeria?

\section{Literature Review}

Adesina et al (2012) opined that globally, Cooperative Societies have become well appreciated as a strong vehicle for promoting economic empowerment particularly of the women, and other vulnerable and marginalised groups. They have continued to play major roles in the economy of many nations. For instance, in the Republic of Kenya, cooperatives are responsible for $45 \%$ of the GDP and $31 \%$ of National Savings and Deposits. They have $70 \%$ of the coffee market, $76 \%$ of dairy, $90 \%$ of pyrethrum, and $95 \%$ of cotton. More than a quarter of a million people are employed directly and effectively by Cooperatives in the country. In South Korea, agricultural cooperatives have a membership of over two million farmers i.e., about nine-tenths of all farmers in the country, and an output of USD 11 billion (Jae-Hak Choi, 2006).

The Korean fishery cooperatives also have a market share of $71 \%{ }^{5}$. In France, the cooperative movement has a turnover of 181 billion Euros. Cooperatives handle $60 \%$ of retail banking, $40 \%$ of food and agricultural production, and $25 \%$ of retail sales ${ }^{6}$. Furthermore, in Canada, about two-fifths of the population belong to at least one cooperative society. In Quebec, approximately $70 \%$ of the population are cooperative members, while in Saskatchewan 56\% are members.

In Nigeria, cooperative system however started around 1935 in Ibadan. It has since been well accepted across the country and has made visible impacts on the socio-economic development of the country over the past seven decades (Kareem et al., 2012). Many businesses started and have been sustained through funding from the cooperative system. The overwhelming relevance of the cooperative system particularly for pursuing economic empowerment at the grassroots level is obviously the main reason why most Government throughout the world continue to identify what needs to be put right to strengthen and support cooperatives societies so that it can function properly according to the laws establishing it. This is with the view to effectively channel supporting funds to the cooperative societies to enable their members have greater access to loans for their businesses. This ultimately is envisaged, will turn around the economy of the local region sustainably and very rapidly.

The cooperative approach to the management of business is not new or distinct to any tribe, race or country. Cooperatives appear more or less simultaneously with the economic and social demands of populations. The overriding question that is yet to be satisfactorily answered is the extent to which the cooperative movement is performing well. Nigeria is one of the few British Colonies that advocated for the establishment of Cooperatives as early as 1900. Some pseudo cooperatives were subsequently established to operate along the ideals of the Rochdale cooperative pioneers of 1844. The Cooperative Ordinance of 1946 and the Cooperative Societies Act of 1962 only served to formalize the already organized cooperatives. The 
performance of cooperatives in the immediate post-colonial period was impressive, with the government offering them a monopoly status in agricultural marketing.

\section{Issues on Sustainable Development Goals}

This Agenda is a plan of action for people, planet and prosperity. It also seeks to strengthen universal peace in larger freedom. It is recognised that eradicating poverty in all its forms and dimensions, including extreme poverty, is the greatest global challenge and an indispensable requirement for sustainable development. All countries and all stakeholders, acting in collaborative partnership, will implement this plan. (UN, Department of Economic and Social Affairs, 2014).

The 17 Sustainable Development Goals and 169 targets demonstrate the scale and ambition of this new universal Agenda. They seek to build on the Millennium Development Goals and complete what these did not achieve. They seek to realize the human rights of all and to achieve gender equality and the empowerment of all women and girls. They are integrated and indivisible and balance the three dimensions of sustainable development: the economic, social and environmental (UN, Department of Economic and Social Affairs, 2014).

\section{Methodology}

The study covered all the 30 local government areas and one area office in Osun state, Nigeria. The state is located in the south western part of Nigeria, it enjoys tropical climate with abundant sunshine and heavy rainfall. Literacy level is about $51.5 \%$ in 2010. The state capital is Osogbo and it is the most urbanised in the region. There are two types of cooperative societies in Osun state: affiliating and non-affiliating cooperative societies. These are divided into six zones within the state. The zones are Ilesa, Ife, Ede, Osogbo, Iwo, and Ikirun.

The study administered 2972 questionnaire in all 1486 cooperative societies in Osun state to cooperative president and a member of each society. Hence, respondents were purposively selected. Respondents in affiliating and non-affiliating societies were contacted through the Department of Cooperatives Services of the Ministry of Commerce, Cooperatives and Empowerment, Osogbo who oversees their activities.

The instruments used for data capturing were developed and pre-tested before their administration. The pre-test was to ensure that the instruments would be able to capture the pertinent data needed for the exercise. The instruments include: (i) A comprehensive questionnaire to capture the various aspects of the activities of Cooperative societies; (ii) A questionnaire for executive members of the cooperative societies.

\section{Findings}

Figure 1 shows the distribution of the cooperative societies by the geopolitical zones of the State. It shows Osogbo zone having a relatively larger number followed by Ikirun and Ife zones. The distribution is fairly representative of the different parts of the state. The dominance of Osogbo zone should be expected. Apart from being the State capital where economic activities are much higher than in any other zones, many of the cooperative societies that came from Oyo State to the new State in 1991 ended up in Osogbo. Also, Osogbo has a long history of being a commercial centre and a strategic nodal town linking the southern part of western Nigeria with the northern part. This vantage position may have supported the presence of a large pool of cooperative societies in the area. 


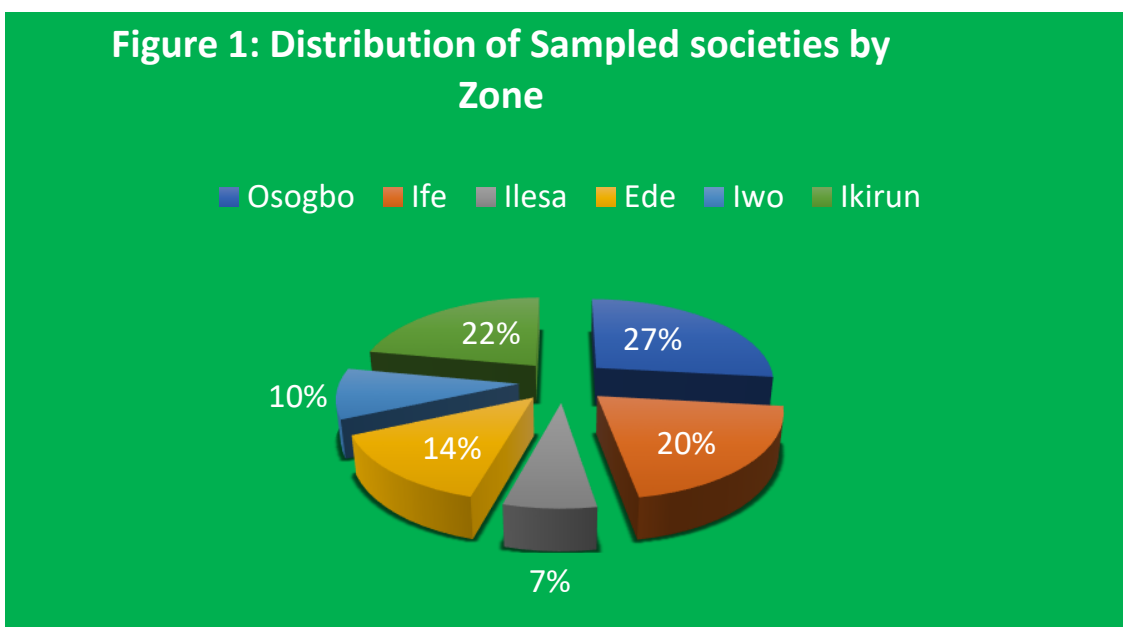

The relatively lower numbers of societies from Iwo and Ijesa zones are by no means suggestive of low cooperative activities in those zones. Rather they indicate in part, a relative inaccessibly of many societies in these areas despite several visits to their local government areas and intensive radio announcements by the researchers. The result suggests to us however the need for societies to build stronger network so that they can interface with each other on various issues.

\section{Categories of Cooperative Societies}

The analysis of the data showed that there are five main categories of Cooperative Societies in the various parts of the State. These are Credit and Thrift cooperatives, Produce Buying Cooperatives, Consumer Cooperative, Producers Cooperatives and Farmers' Cooperative. To this may be added a sixth category - Multi-purpose cooperatives.

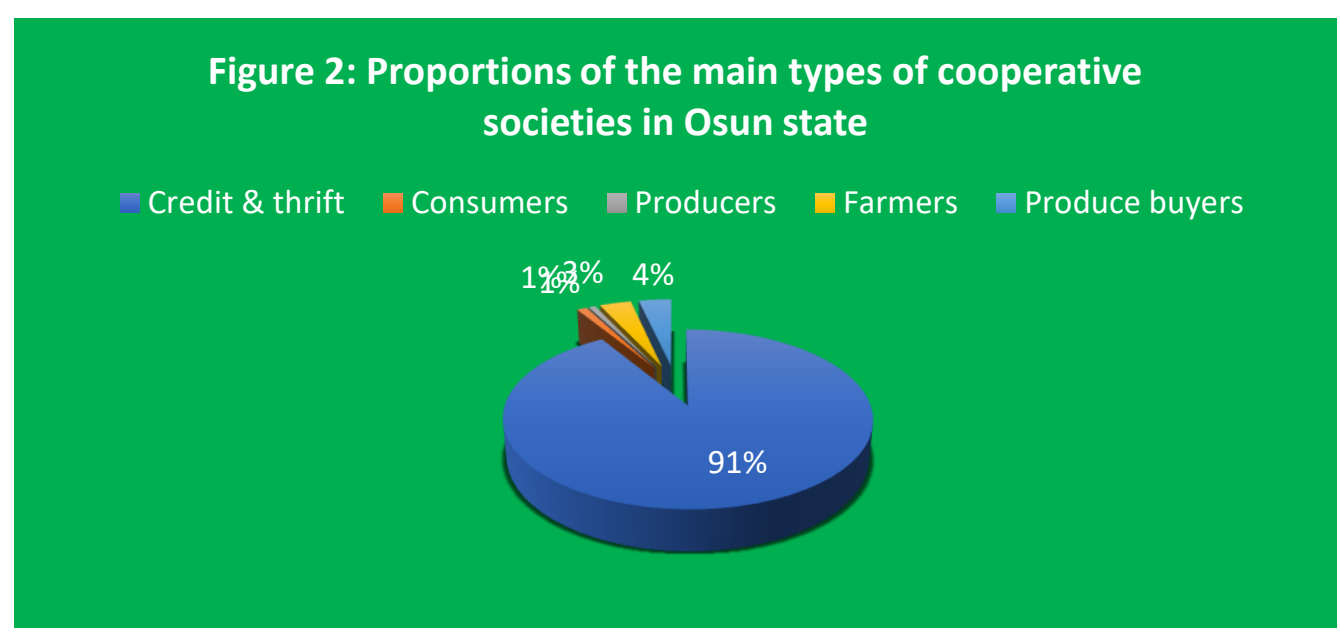

From the Figure 2. it is clear that the Credit and Thrift Cooperative Societies constitute the dominant type in the State representing nine-tenths of the societies covered. These societies basically encourage thrift among their members and help them to meet their loan needs, preventing them from predatory lenders. A large proportion of these societies are market women, petty traders and artisans. Although the category make-up the dominant group, the 
capital investments of its societies are relatively small. In terms of strategic relevance for wealth creation and poverty reduction through economic empowerment, this is a group of societies that government would need to target. They are visible group particularly on their regular meeting days and among them are several individuals who need less than N10,000 to run the petty businesses they engage in.

Produce buying societies are the next most important group of cooperative societies although it is only $4 \%$ of the total.

The Cocoa Producing and Marketing Union (CPMU) which is one of the very well-established societies in Ile-Ife facilitates the buying of Cocoa in particular from farmers and also its bulk sales. Other small farmers' Cooperatives work jointly in various forms including securing farm inputs and thereby enjoying the benefits of large-scale farming. Given the significant status of tree-based farm produce in the local economy, this category of cooperatives needs further strengthening. If properly managed, the State can derive more benefits from the sector by being more active in providing funding support for the buying of the produce.

The Farmers' Cooperative Societies representing only 3\% are the next group of societies. This group is small but strategic to the aggressive socio-economic development efforts of the Government. The other two groups are rather small in number each accounting for about $1 \%$ of the total. These are: Consumer and Producers Cooperative Societies. These societies are formed to protect the interests of consumers which include non-members, by making essential goods available at the controlled prices. The societies buy goods in large quantities and byepass the middlemen in the process of distribution. As depicted in Figure 3, most members are 36 years and above. Less than a third of membership are up to 35 years and more than a tenth are above 60 years. This implies that older people who had enjoyed the benefit of cooperative system are still active members of the cooperative movement.

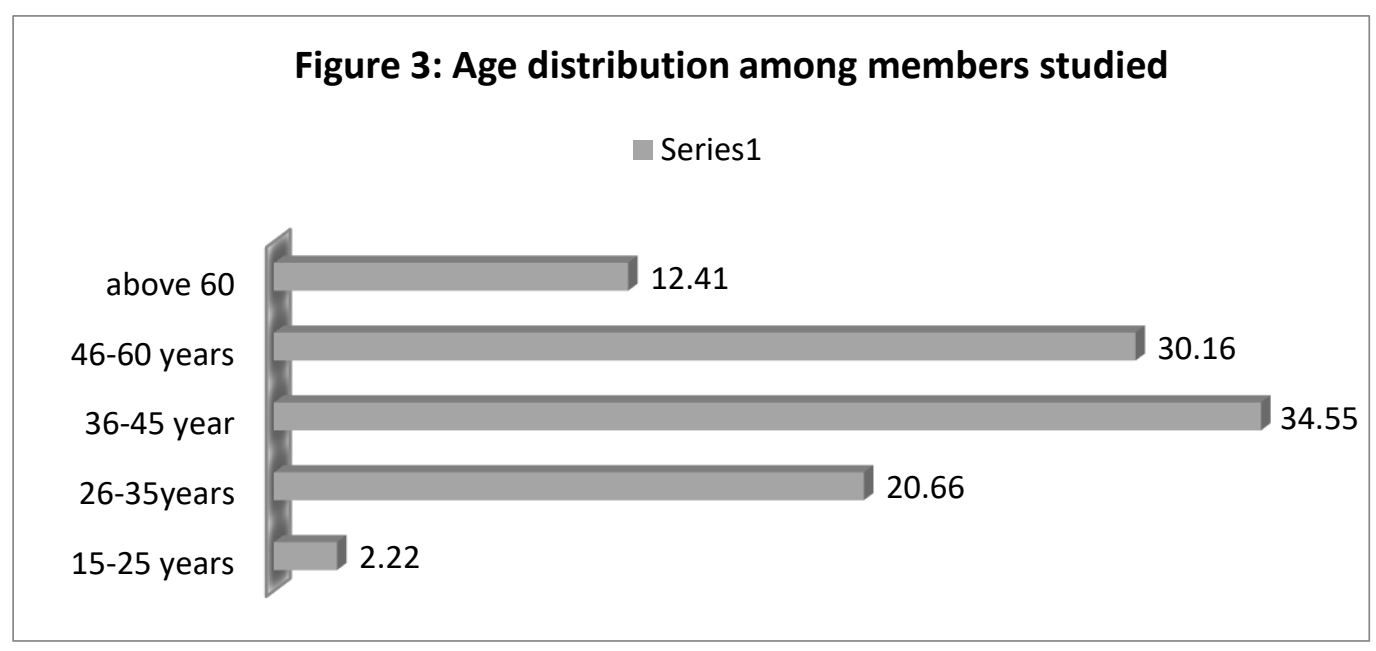

This result emphasises the importance of cooperative societies as reported in literature. (Virendra Kumar et al, 2015). It may also be that the cooperative system is not responding well to the special needs and perceptions of young people. Sensitisation has to be invested in to drawing young people into the movement.

The ages of executive members are depicted in Figure 4. Very few - less than $12 \%$ of younger people are members of the executive. The executives are dominated by persons who are 48 
years and above. This means that the cooperative movement is probably still dominated by those who have been in it for a long time. This has to be addressed. For empowerment, young people who are up to 18 years old should be encouraged not only to be members of societies but to be willing to assume leadership positions which will help to inject innovative ideas into the societies and improving their entrepreneurial pursuit. The deliberate efforts of the government of Nigeria to support new groups particularly artisans who could eventually become cooperative societies is in the right direction.

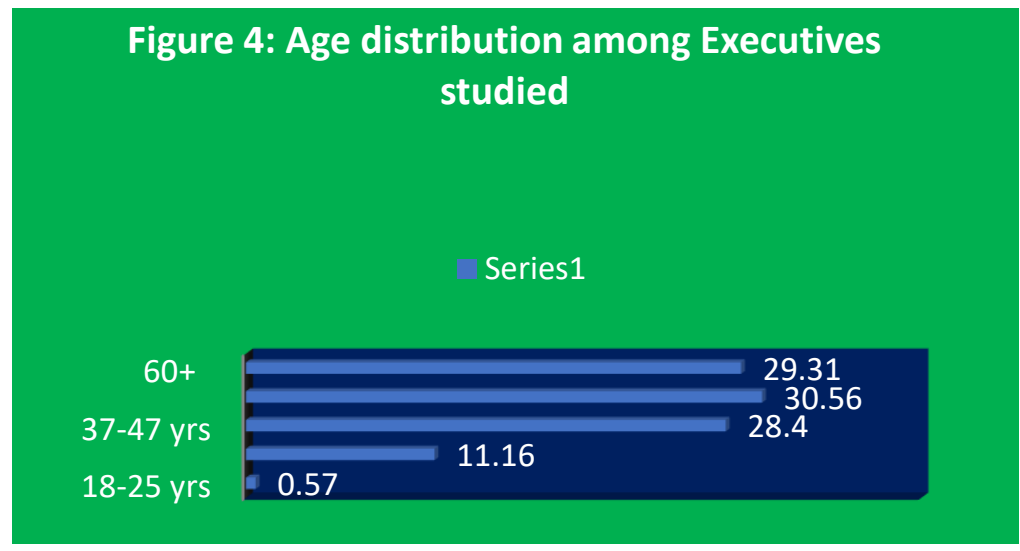

\section{Investment}

Investing in ventures is another source of income for cooperative societies. Societies with good investments are able to give high dividends and can give loans at very low interest rates (sometimes at zero rates) to their members. In general, the older the societies are, the greater the chances that they would have wider ranges of investments. As shown in Figure 5, close to three-fifths $(58.2 \%)$ of the cooperative societies have investments of various types.

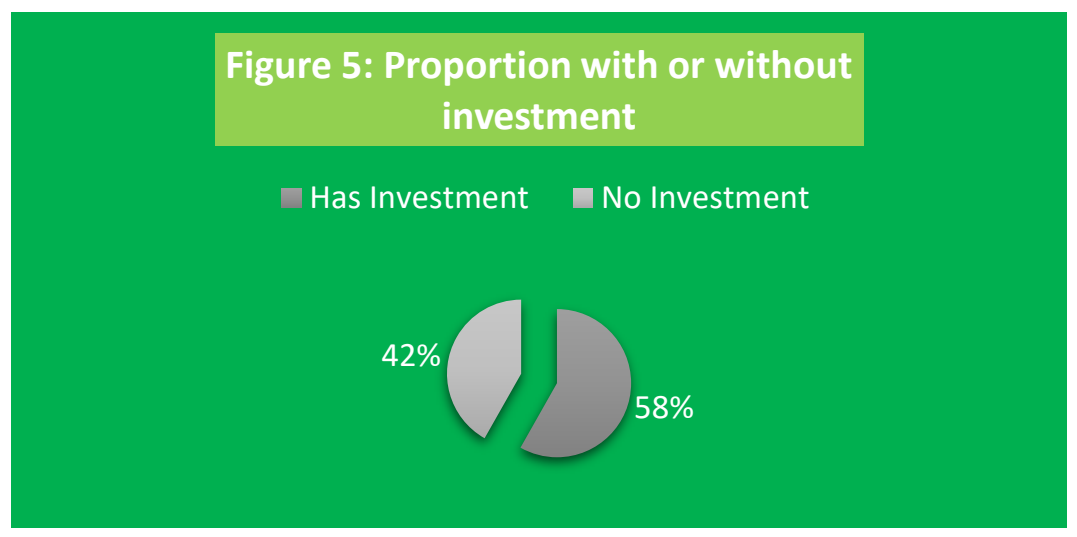

As depicted in Figure 5, most of these investments are on land and landed properties as well as rental services. Common landed properties mentioned are multi-purpose halls and meeting places as well as housing units. Only few societies invest in motor vehicles and shares. The societies are generally careful about their choice of what to invest upon to ensure that their money does not get lost in the process and in any case, that the efforts bring good returns. Most societies believe that landed properties are safe to invest in.

\section{Discussion}

The study was able to identify major contributions of cooperative societies using relevant subheadings, which are sometimes posed as questions. For example, what are the contributions of cooperatives to alleviate poverty from their members and to national development? 
Economic significance

The significance of cooperatives for development in any nation cannot be over emphasized. In the early days, cooperatives assisted the less privileged to improve their living conditions. Despite the current lukewarm performance, they continue to offer employment opportunities to many people, especially women and the youth. They have contributed to poverty reduction through the establishment of income generating activities and the offering of employment opportunities. Cooperatives provide social protection through educating members on health issues.

The establishment of specialized innovative cooperative enterprises, such as rural electrification, rural water, and indigenous community service farms is likely to enhance development in the rural area. Large numbers of cooperatives participate in marketing of agricultural inputs and produce. As a result, a significant proportion of cooperative unions are engaged in marketing of agricultural produce (Bernard et al., 2008). Cooperatives provide marketing options for the members and non-members, though the members receive higher prices for their produce. Cooperative unions are involved in export and domestic marketing activities, financial transactions, and social capital development. The economic role of cooperatives is significant in terms of foreign currency earning for their countries.

Unions provide multiple services to their members. Example of a major service delivered by cooperative unions to primary cooperatives is that of importation of agricultural inputs, such as fertilizer, seeds, and chemicals, and distribute these inputs to members at reasonable prices. It should be noted however that these achievements were possible due to the collateral provided by their investments, without which bank loans for importing fertilizer would not have been possible to obtain. Some cooperative unions provide machinery renting services to cooperative members in order to introduce modern farming techniques at lower rental prices Cooperative unions purchase agricultural produce from members at a competitive price and offer dividend on share capital to their members. The primary cooperatives get loans through unions and sell agricultural commodities to unions, which then sell the commodities in local and export markets. Other services cooperative unions provide to members include transportation of produce, storage of produce, credit, and facilitation of training to primary cooperatives. The extent to which the services offered by cooperative unions meet the demands and needs of the members varies on a case-by-case basis.

Employment creation, income generation, poverty reduction and environmental sustainability Every union has a manager and primary cooperatives employ different numbers of permanent and casual workers. If one should calculate the number of managers that each cooperative society has then the number will be so enormous for example Osun State has almost 1,500 societies this means that they have helped in solving part of unemployment problems that the country is facing. It was noted that UN Habitat, the UN agency for human settlements, has endorsed the idea of cooperative housing as part of its strategy and sees an expanding role for them, particularly in Eastern and Southern Africa. The Swedish Cooperative Centre is also supporting NGOS working to expand the housing cooperative sector in Zimbabwe, South Africa, Kenya and Vietnam. It is too early to tell whether these initiatives will be successful, but they are building on existing organisations, and are aiming to meet not just the need for housing but also for security of tenure, income-generation, clean water and sanitation, savings and credit, and so on. In Nigeria, cooperative societies have also acquired acres of land for building purposes for members, they also helped to acquire all necessary documentation to avoid unnecessary embarrassment and insecurity. 


\section{Institutional capacity building}

The key service the Ministry of Cooperative provides is technical advice to the Federation offices and the cooperative unions. Generally, the Ministry and the respective federation are involved in promotion, organizing, registration, regulation, inspection, auditing and giving technical support to cooperatives works more on capacity building and on improving the networking of cooperative organizations. The training given by government and other institution supports institutional capacity building and has helped create a more stable and functional environment for cooperative unions.

How can cooperative societies be better positioned to achieve the Sustainable Development Goals in Nigeria?

An overwhelming majority of the cooperative societies studied have not had any form of support from government or any NGO. Just about $4.6 \%$ had ever had any form of benefits from government or NGO. In the specific, every support received by few societies are mostly from UNDP and Community Development Fund (CDF). Among the government programmes involved in loan schemes for cooperative farming was the Family Economic Advancement Programme (FEAP). For example, by the end of August 1998, loans approved to cooperative farmers in Ondo and Osun states under the scheme were more than one hundred million naira in each state.

Government's direct supports mentioned included NAPEP, QIIP, and Agricultural Loan. More than $90 \%$ of those who took the loan had paid back in full. Although government intervention had been minimal, there are good indications to show that cooperative societies will pay if given loan support by government. The Cooperative Societies interacted with are desirous of government support in terms of facilitating greater access to loan to grow and or run their businesses. When asked about how the government should go about providing loans to strengthen the cooperative societies. Many societies wished that support should come directly to them from Government and not through any umbrella body who may not give them anything at the end. Therefore, if they are supported by the government in the area of disbursement of loan, there is possibility for the societies to meet the needs of their members and thereby achieving poverty eradication. Capacity building for the executives and the members are advised from time to time.

What are the factors affecting the performance of cooperatives in Nigeria?

The study was able to identify different kinds of challenges that the cooperative societies are faced with in Nigeria; among which are: The registration process is complicated as many qualified Societies complained to us about the challenges of getting registered with the government. Also, high interest rates from government financial intervention as expressed by representatives of societies who have benefitted from such constitute another challenge. Most of the members of the cooperative societies complained of the lateness in disbursement of loan thereby affecting their entrepreneurial pursuit. Mismanagement of available funds amongst the executives of the cooperatives as revealed by the members sampled is another great challenge faced by the members.

\section{Conclusions}

These challenges from the government are to be taken into consideration in subsequent government interventions. The interest rate should not be too high. It should be noted that some societies are already giving members loans with zero interest. Also, the strategy of loan disbursement should be such that guarantee easy access and fairness. It is recommended 
therefore that study of cooperative society should be included in the tertiary institutions curricula which we have done in OAU, this serves as the uptake of our Institute after the research. Also, a model cooperative society was formed in OAU for other cooperative to follow. This has achieved a lot of growth in that it started in 2014 with 30 membership and has grown to almost a thousand membership.

\section{References}

Adesina, F.A. (2012) "Restructuring the Cooperative Societies in the State of Osun in Nigeria" being a report submitted to the Executive Governor of Osun State on How to move Osun State forward. September.

Adeyemo, R and Bamire, S. (2005), Saving and Investment Patterns of Cooperative Farmers in Southwestern Nigeria, Journal of Social Sciences, 11(3), 183-192.

Bernard, T., Taffesse, A. S., \& Gabre-Madhin, E. (2008). Impact of cooperatives on smallholders' commercialization behavior: evidence from Ethiopia. Agricultural Economics, 39(2), 147-161.

Birchall, J. (2004). Cooperatives and the Millennium Development Goals. Cooperative Branch \& Policy Integration Department International Labour Office, Geneva.

Dominic Okereke (2012) Africa's Quiet Revolution; Observed from Nigeria. Paragon Publishing Northampton UK. ISBN 978-1-908341-87-7

Ejiogu, A. O. (2015). Assessing the activities of Self-Help Groups in social protection in Southeast Nigeria. Asian Journal of Agricultural Extension, Economics \& Sociology, $1-15$.

ICA (1995) "Statement on the Cooperative Identity", Report to the 31st Congress Manchester, in Review of International Cooperation, 88.3

Impact of Cooperative Societies www.ica.coop/coop/statistics.html. International Cooperative Alliance's Statement on the Co-operative Identity

Jae-Hak Choi (2006) FFTC-NACF International Seminar on Agricultural Cooperatives in Asia: Innovations and Opportunities in the 21st Century, Seoul, Korea, 11-15 September 2006 Agricultural Cooperatives in Korea.

Kareem, R. O., Arigbabu, Y. D., Akintaro, J. A., \& Badmus, M. A. (2012). The Impact of Cooperative Society on Capital Formation (A Case Study of Temidere Co-Operative and Thrift-Society, Ijebu-Ode, Ogun State, Nigeria). Global Journal of Science Frontier Research Agriculture and Veterinary Sciences, 12(11), 17-29.

Onyeaghocha S. (2008). Comparative study of the methods and performance of micro finance institution in south eastern Nigeria Central Bank of Nigeria Economic and Financial review Vol. 39, No 4., pp. 243-269.

Otto, G. and Ukpere, W. (2011), Credit and thrift co-operatives in Nigeria: A potential source of capital formation and employment, African Journal of Business Management, 5(14), pp. 5675-5680.

Virendra Kumar, K. G. Wankhede, H. C. Gena (2015). Role of Cooperatives in Improving Livelihood of Farmers on Sustainable Basis. Asian Journal of Agricultural Extension, Economics \& Sociology, 5(1), pp. 1-15. 